\title{
Resource use and costs associated with opioid- induced constipation following total hip or total knee replacement surgery
}

This article was published in the following Dove Press journal: Journal of Pain Research

\author{
Eric T Wittbrodt ${ }^{\prime}$ \\ Tong J Gan ${ }^{2}$ \\ Catherine Datto' \\ Charles McLeskey' \\ Meenal Sinha ${ }^{3}$ \\ 'US Medical Affairs, AstraZeneca, \\ Wilmington, DE, USA; ${ }^{2}$ Department \\ of Anesthesiology, Stony Brook \\ Medicine, Stony Brook, NY, USA; \\ ${ }^{3}$ Premier Applied Sciences, Premier, \\ Inc., Charlotte, NC, USA
}

Purpose: Constipation is a well-known complication of surgery that can be exacerbated by opioid analgesics. This study evaluated resource utilization and costs associated with opioidinduced constipation (OIC).

Patients and methods: This retrospective, observational, and propensity-matched cohort study utilized the Premier Healthcare Database. The study included adults $\geq 18$ years of age undergoing total hip or total knee replacement as inpatients who received an opioid analgesic and were discharged between January 1, 2012, and June 30, 2015. Diagnosis codes identified patients with OIC who were then matched 1:1 to patients without OIC. Generalized linear and logistic regression models were used to compare inpatient resource utilization, total hospital costs, inpatient mortality, and 30-day all-cause readmissions and emergency department visits. Results: Of 788,448 eligible patients, 40,891 (5.2\%) had OIC. Covariates were well balanced between matched patients with and without OIC ( $n=40,890$ each). In adjusted analyses, patients with OIC had longer hospital lengths of stay (3.6 versus 3.3 days; $p<0.001$ ), higher total hospital costs (US\$17,479 versus US\$16,265; $p<0.001)$, greater risk of intensive care unit admission (odds ratio $[\mathrm{OR}]=1.12,95 \% \mathrm{CI}: 1.01-1.24$ ), and increased likelihood of 30-day hospital readmissions (OR=1.16, 95\% CI: $1.11-1.22)$ and emergency department visits (OR=1.38, 95\% CI: $1.07-1.79)$ than patients without OIC. No statistically significant difference was found with inpatient mortality (OR=0.89, 95\% CI: $0.59-1.35$ ).

Conclusion: OIC was associated with greater resource utilization and hospital costs for patients undergoing primarily elective total hip or total knee replacement surgery. These results support OIC screening and management strategies as part of perioperative care management.

Keywords: opioids, opioid-induced constipation, pain management, knee and hip replacement surgery, health care resource utilization, length of stay, costs, intensive care admissions, hospital readmissions, emergency department visits

\section{Plain language summary}

Constipation commonly occurs after surgery, and the use of opioids for postoperative analgesia can worsen constipation. This retrospective study evaluated hospital resource utilization and costs associated with opioid-induced constipation (OIC) in patients undergoing total knee or total hip replacement procedures in an inpatient setting. These outcomes were evaluated using data for adult patients who received an opioid analgesic for postoperative pain management from a large US administrative hospital database. Patients with OIC were identified and matched with patients without OIC, and resource utilization was compared between these 2 patient groups. This study included $>780,000$ patients, and $\sim 5 \%$ of those patients had OIC. On average, the length of time spent in the hospital was longer ( 0.3 days) and average hospital costs were significantly higher ( US\$1200) for patients with OIC. In addition, patients with OIC had a greater risk of being
Correspondence: Eric T Wittbrodt US Medical Affairs, AstraZeneca, 1800 Concord Pike, Wilmington, DE 19803, USA

Tel + I 3028851603

$\mathrm{Fax}+\mathrm{I} 3028859637$

Email eric.wittbrodt@astrazeneca.com 
admitted to an intensive care unit and of being readmitted to the hospital within 30 days than patients without OIC. Taken together, these results indicate that OIC is associated with greater resource utilization and costs for patients undergoing primarily elective total hip or total knee replacement surgery. These results indicate that screening for and managing OIC may be beneficial for improving patient outcomes during postoperative care.

\section{Introduction}

Opioid-induced constipation (OIC) is a common adverse effect of opioid analgesics. ${ }^{1-5}$ Determining the exact prevalence of OIC is challenging because of many factors, including variations in how constipation is defined, reported, and/ or collected; the specific opioid(s) used; treatment setting; patient population; and the frequency of opioid use. ${ }^{1,6,7}$ Among patients with chronic non-cancer pain receiving opioids for months to years, rates of OIC range from $\sim 5 \%-49 \%$ in studies using health claims data, ${ }^{8-10} \sim 15 \%-41 \%$ in systematic reviews of clinical trials, ${ }^{5-7}$ and $\sim 15 \%-81 \%$ from patient- or provider-reported survey studies. ${ }^{11-15} \mathrm{OIC}$ in patients with chronic non-cancer pain has been shown to increase health care utilization and costs ${ }^{8,10,13}$ and decrease patient satisfaction with treatment, health-related quality of life, and work productivity. ${ }^{11,16-18}$ Opioids are also frequently used in acute care settings for shorter durations, such as for postoperative pain management. However, little is known about the occurrence of OIC or the health care utilization and costs associated with OIC in these patients. ${ }^{19,20}$

This study sought to evaluate hospital resource utilization and costs associated with OIC in patients undergoing total knee or total hip replacement procedures. Total knee and total hip replacements are commonly performed, with an estimated 7,200,000 procedures performed in the USA in $2010 .{ }^{21}$ Given the frequency of these procedures, high likelihood of preoperative chronic pain in the affected joint with the potential need for opioid therapy, and the requirement for postoperative pain management that frequently includes opioid analgesics, this surgical patient population was ideal for initial exploration of the real-world health care burden associated with OIC in an acute care setting.

\section{Patients and methods Study design and data source}

This retrospective, observational, and propensity-matched cohort study utilized the Premier Healthcare Database (PHD), which is a large geographically diverse US administrative hospital database that represents the 4 US Census regions and 9 divisions. The PHD includes a subset of data from the Premier Quality Advisor ${ }^{\mathrm{TM}}$ Platform, which offers deidentified, Health Insurance Portability and Accountability Act (HIPAA)-compliant data. ${ }^{22}$ The PHD provides hospital-, payer-, service-, and patient-level data. Patient-level data include demographics, all International Classification of Diseases (ICD)-9 diagnosis and procedure codes, and billed medications and medical devices. Using masked identifiers, patients can be tracked in the same hospital across inpatient and outpatient settings. The use of PHD data in the current study did not require Institutional Review Board approval, according to Title 45 Code of Federal Regulations (CFR) Part 46, specifically 45 CFR 46.101(b)(4). Furthermore, in compliance with the HIPAA Privacy Rule, disclosed PHD data are considered de-identified per 45 CFR 164.506(2)(2) (ii)(B), via the "Expert Determination" method. ${ }^{22}$

\section{Patient population and study groups}

Patients $\geq 18$ years of age admitted to the hospital for total knee or total hip replacement (ICD-9 codes 81.51 and 81.54, respectively) and discharged between January 1, 2012 and June 30, 2015, were identified in the PHD. Among these patients, those with charges in the pharmacy billing record for 1 or more doses of selected opioid analgesics (morphine, codeine, dihydrocodeine, fentanyl, hydrocodone, hydromorphone, levorphanol, meperidine, methadone, oxycodone, oxymorphone, tapentadol, and tramadol) on or after the day of surgery were identified for the study cohort. Only the first qualifying hospitalization for each unique patient was selected. Patients with missing cost data were excluded from the study cohort. The study cohort was then divided into those with and without OIC. Because there is no specific diagnosis code for OIC, the following ICD-9 diagnosis or procedure codes from the index hospitalization were used: $564.0 \mathrm{X}$ (constipation), 560.30 (impaction of intestines, unspecified), 560.32 (fecal impaction), 560.39 (impaction of intestine, other), 560.89 (other specified intestinal obstruction), 564.7 (megacolon, other than Hirschsprung's), 96.38 (removal of impacted feces), or 96.39 (transanal enema). ${ }^{8}$

\section{Patient and hospital characteristics}

Patient demographics (age, sex, and race), payer (Medicare, Medicaid, managed care, and other), admission source (home, transfer from other facility, and other), type (emergency, elective, urgent, trauma, and other), and hospital characteristics (geographic division, bed capacity, urban/rural location, and teaching/non-teaching status) were obtained for the index hospitalization. The presence of Deyo-Charlson comorbidities during the index hospital encounter (myocardial 
infarction, heart failure, peripheral vascular disease [PVD], cerebrovascular disease, dementia, chronic pulmonary disease, rheumatologic disease, peptic ulcer disease, mild liver disease, moderate-to-severe liver disease, diabetes without complications, diabetes with chronic complications, hemiplegia or paraplegia, renal disease, any malignancy, including leukemia or lymphoma, metastatic solid tumor, and AIDS/ HIV) along with the Deyo-Charlson Comorbidity Index (CCI) were also determined from the index hospitalization. ${ }^{23}$ In addition, discharge diagnosis codes for chronic pain (ICD-9 code 338.2x) and hemodialysis (ICD-9 V56) were identified. A diagnosis of chronic pain may be an indicator of opioid use prior to hospitalization, while dialysis is associated with higher rates of constipation. ${ }^{24}$

The total number of hospitalized days in which an opioid charge occurred and the total oral morphine equivalents (mg) charged during the hospitalization were determined to estimate opioid exposure. ${ }^{25}$ Charges in the pharmacy billing record for 1 or more selected medication classes also associated with the potential to cause constipation were identified (levodopa, antidepressants, antipsychotics, antihypertensives, anticonvulsants, and muscle relaxants). Use of peripheral $\mu$-opioid receptor antagonists (alvimopan, methylnaltrexone, and naloxegol) and selected pro-motility medications or stool softeners (lubiprostone, linaclotide, and docusate) were also identified.

\section{Study outcomes}

Outcomes of interest related to resource utilization included total index hospital length of stay (LOS), admission to an intensive care unit (ICU) during the index hospitalization (yes or no), and ICU LOS during the index hospitalization. Total patient cost for the index hospitalization was also determined using the hospital charge master records, which includes costs for room and board, laboratory, pharmacy, surgery, supply, and all other direct patient care expenses. Clinical outcomes of interest included death during the index hospitalization, all-cause 30-day hospital readmission, and all-cause 30-day subsequent emergency department (ED) visits. Only readmissions and subsequent ED visits to the same hospital as the index hospitalization are available in the PHD. The 30-day observation period began on the date of discharge for the index hospitalization. Patients who died during the index hospitalization were excluded from the readmission and subsequent ED visits analyses.

\section{Statistical analysis}

A propensity-matched cohort of patients with and without OIC was created to balance covariates. A propensity score for each patient was determined by creating a logistic regression model for the probability of OIC versus no OIC. Covariates in the model were selected using a backward selection process including the following: age, sex, race, Charlson comorbidities (COPD, diabetes, hemiplegia, malignancy, mild liver disease, moderate liver disease, PVD, rheumatologic disease, and peptic ulcer disease), chronic pain, hemodialysis, constipation-related medications, hospital geographic divisions, teaching status, selected hospital day on which first opioid was given, and hospital day on which surgery took place. Matching of patients with and without OIC was performed using Mahalanobis metric matching within calipers on a $1: 1$ basis. $^{26}$

Characteristics and unadjusted outcomes of patients with and without OIC in the unmatched and matched cohorts are presented in Table 1. Continuous variables are presented as means and SDs, and univariate comparisons were made

Table I Patient and hospital characteristics for matched cohorts with and without $\mathrm{OIC}^{\mathrm{a}}$

\begin{tabular}{|c|c|c|c|c|}
\hline & \multicolumn{4}{|c|}{ Matched cohort, $\mathrm{N}=\mathbf{8} 1,780$} \\
\hline & All & $\begin{array}{l}\text { With } \\
\text { OIC, } \\
n=40,890\end{array}$ & $\begin{array}{l}\text { Without } \\
\text { OIC, } \\
n=40,890\end{array}$ & $p$-value \\
\hline Age, years, mean (SD) & $68(11)$ & $68(\mathrm{II})$ & $68(11)$ & 1.00 \\
\hline Sex, men & 37.0 & 37.1 & 36.9 & 0.68 \\
\hline \multicolumn{5}{|l|}{ Race } \\
\hline Caucasian & 81.5 & 81.3 & 81.6 & \multirow{3}{*}{0.50} \\
\hline Black & 8.0 & 8.0 & 7.9 & \\
\hline Other & 10.6 & 10.7 & 10.5 & \\
\hline \multicolumn{5}{|l|}{ Payer } \\
\hline Medicare & 63.4 & 63.6 & 63.1 & \multirow{4}{*}{$<0.001$} \\
\hline Medicaid & 3.3 & 3.8 & 2.9 & \\
\hline Managed care & 23.5 & 22.6 & 24.2 & \\
\hline Other & 9.8 & 10.1 & 9.6 & \\
\hline \multicolumn{5}{|l|}{ Admission source } \\
\hline Home & 98.4 & 98.5 & 98.4 & \multirow{4}{*}{0.82} \\
\hline $\begin{array}{l}\text { Transferred from acute } \\
\text { care facility }\end{array}$ & 0.8 & 0.8 & 0.8 & \\
\hline $\begin{array}{l}\text { Transferred from } \\
\text { skilled nursing facility }\end{array}$ & 0.2 & 0.2 & 0.2 & \\
\hline Other/unknown & 0.6 & 0.6 & 0.6 & \\
\hline \multicolumn{5}{|l|}{ Admission type } \\
\hline Elective & 92.8 & 93.4 & 92.3 & \\
\hline Emergency & 3.1 & 3.4 & 2.7 & \\
\hline Trauma & 0.1 & 0.1 & 0.1 & $<0.001$ \\
\hline Urgent & 3.7 & 2.7 & 4.7 & \\
\hline Other & 0.3 & 0.3 & 0.3 & \\
\hline \multicolumn{5}{|l|}{ Comorbidities during } \\
\hline \multicolumn{5}{|l|}{ index encounter } \\
\hline Myocardial infarction & 4.2 & 4.4 & 4.0 & 0.005 \\
\hline Heart failure & 3.7 & 4.1 & 3.3 & $<0.001$ \\
\hline $\begin{array}{l}\text { Peripheral vascular } \\
\text { disease }\end{array}$ & 3.0 & 3.0 & 3.0 & 0.79 \\
\hline
\end{tabular}

(Continued) 
Table I (Continued)

\begin{tabular}{|c|c|c|c|c|}
\hline & \multicolumn{4}{|c|}{ Matched cohort, $\mathbf{N}=\mathbf{8} I, 780$} \\
\hline & All & $\begin{array}{l}\text { With } \\
\text { OIC, } \\
n=40,890\end{array}$ & $\begin{array}{l}\text { Without } \\
\text { OIC, } \\
n=40,890\end{array}$ & p-value \\
\hline $\begin{array}{l}\text { Cerebrovascular } \\
\text { disease }\end{array}$ & I.I & I.I & 1.0 & 0.15 \\
\hline Dementia & 0.1 & 0.1 & 0.1 & 0.67 \\
\hline $\begin{array}{l}\text { Chronic pulmonary } \\
\text { disease }\end{array}$ & 18.2 & 18.3 & 18.2 & 0.67 \\
\hline Rheumatologic disease & 4.9 & 4.9 & 4.9 & 0.83 \\
\hline Peptic ulcer disease & 0.8 & 0.8 & 0.8 & 0.97 \\
\hline Mild liver disease & 0.4 & 0.4 & 0.4 & 0.96 \\
\hline $\begin{array}{l}\text { Moderate-to-severe } \\
\text { liver disease }\end{array}$ & 0.0 & 0.0 & 0.0 & 1.00 \\
\hline Diabetes & 19.2 & 19.3 & 19.1 & 0.60 \\
\hline $\begin{array}{l}\text { Diabetes with chronic } \\
\text { complications }\end{array}$ & 1.8 & 2.1 & 1.5 & $<0.001$ \\
\hline $\begin{array}{l}\text { Hemiplegia or } \\
\text { paraplegia }\end{array}$ & 0.1 & 0.1 & 0.1 & 1.00 \\
\hline Renal disease & 7.1 & 8.3 & 5.8 & $<0.001$ \\
\hline Any malignancy & 1.4 & 1.4 & $\mathrm{I} .4$ & 0.77 \\
\hline Metastatic solid tumor & 0.3 & 0.3 & 0.3 & 0.81 \\
\hline AIDS/HIV & 0.1 & 0.1 & 0.0 & 0.22 \\
\hline $\begin{array}{l}\text { Charlson Comorbidity } \\
\text { Index, mean (SD) }\end{array}$ & $0.8(1.2)$ & $0.9(1.3)$ & $0.8(I . I)$ & $<0.001$ \\
\hline Chronic pain & 7.1 & 7.1 & 7.1 & 1.00 \\
\hline Hemodialysis & 0.4 & 0.4 & 0.4 & 0.91 \\
\hline $\begin{array}{l}\text { Use of peripheral } \\
\mu \text {-opioid receptor } \\
\text { antagonists }\end{array}$ & 0.5 & 1.0 & 0.1 & $<0.001$ \\
\hline $\begin{array}{l}\text { Use of selected pro- } \\
\text { motility drugs and stool } \\
\text { softeners }\end{array}$ & 87.2 & 88.5 & 85.9 & $<0.001$ \\
\hline $\begin{array}{l}\text { Total oral morphine } \\
\text { equivalents }(\mathrm{mg}) \text { for index } \\
\text { hospitalization, mean (SD) }\end{array}$ & $\begin{array}{l}129.7 \\
(223.2)\end{array}$ & $\begin{array}{l}129 \\
(236.7)\end{array}$ & $\begin{array}{l}130.3 \\
(208.7)\end{array}$ & 0.44 \\
\hline $\begin{array}{l}\text { Total days of opioid use, } \\
\text { mean (SD) }\end{array}$ & $3.3(1.9)$ & $3.5(2.1)$ & $3.2(1.7)$ & $<0.001$ \\
\hline Hospital geographic & & & & \\
\hline divisions & & & & \\
\hline New England & 3.2 & 3.2 & 3.1 & \\
\hline Middle Atlantic & 14.8 & 14.7 & 14.8 & \\
\hline East North Central & 19.6 & 19.6 & 19.7 & \\
\hline West North Central & 8.9 & 8.9 & 8.8 & \\
\hline South Atlantic & 22.7 & 22.5 & 22.9 & 0.93 \\
\hline East South Central & 9.9 & 9.9 & 9.9 & \\
\hline West South Central & 7.5 & 7.6 & 7.5 & \\
\hline Mountain & 5.5 & 5.5 & 5.4 & \\
\hline Pacific & 8.0 & 8.1 & 7.9 & \\
\hline Hospital bed capacity & & & & \\
\hline$<150$ & 11.9 & 12.8 & II.I & \\
\hline $150-249$ & 15.9 & 15.0 & 16.9 & \\
\hline $250-349$ & 21.0 & 20.4 & 21.6 & Iחחר \\
\hline $350-449$ & 16.8 & 15.6 & 17.9 & $<0.001$ \\
\hline $450-549$ & 16.3 & 18.2 & 14.5 & \\
\hline$\geq 550$ & 18.1 & 18.1 & 18.1 & \\
\hline Hospital - urban setting & 90.3 & 90.7 & 90.0 & 0.0003 \\
\hline Teaching hospital & 47.3 & 47.3 & 47.4 & 0.86 \\
\hline
\end{tabular}

Note: ${ }^{\text {aAll }}$ values are $\%$ unless otherwise specified.

Abbreviation: OIC, opioid-induced constipation. using Student's $t$-tests. Categorical variables are presented as numbers and percentages, and univariate comparisons were made using chi-squared tests. For all comparisons, a $p$-value of $<0.05$ was considered statistically significant.

Adjusted analysis employed multivariate linear models (PROC GENMOD) to estimate the difference in continuous outcomes, hospital LOS, and total patient costs. The following variables were included in the models: age, race, admission source, admission type, all 17 of the Charlson comorbidities, chronic pain, hemodialysis, constipationrelated medication, use of peripheral $\mu$-opioid receptor antagonists, oral morphine equivalents, total days of opioid use, hospital geographic divisions, urban or rural setting, teaching status, ICU stay, and OIC. These variables had significant variance; therefore, recycled prediction methodology with a log link and gamma distribution was applied for the parameter estimates and $95 \%$ CIs. ${ }^{27}$

Logistic (PROC LOGISTIC) regression models were used to examine the associations between OIC versus no OIC, and risk of ICU admission, inpatient mortality, 30-day all-cause re-hospitalization, and 30-day all-cause subsequent ED visit. The models included the same covariates as the multivariate linear models.

All analyses were performed with SAS software package 9.4 (SAS Institute, Cary, NC, USA).

\section{Results}

Study population

A total of 836,386 patients with total knee $(545,317)$ or total hip $(291,069)$ replacement surgery were identified during the study period. Of these, 789,613 patients $(94.4 \%)$ received an opioid during their hospital stay, and 788,448 patients (94.3\%) met all criteria for inclusion in the analysis. OIC was identified in 40,891 (5.2\%) patients. Therefore, the final propensity-matched cohort included a total of 81,780 patients (40,890 patients with OIC and 40,890 patients without OIC).

\section{Patient and hospital characteristics}

Patient and hospital characteristics of the overall cohort and the matched cohort are presented in Table S1 and Table 1, respectively. The propensity score model had an acceptable goodness of fit with a c-statistic of 0.68 . After propensity matching, the 2 cohorts were balanced on age, sex, race, and admission source, as well as most comorbidities, including chronic pain and hemodialysis. Small but statistically significant differences in payer mix, myocardial infarction ( $4.3 \%$ versus $4.0 \%)$, heart failure $(4.1 \%$ versus $3.3 \%)$, diabetes with complications ( $2.1 \%$ versus $1.5 \%)$, and renal 
disease $(8.3 \%$ versus $5.8 \%$ ) were found between those with versus without OIC, respectively. In addition, the CCI was statistically significantly higher in those with OIC $(0.9 \pm 1.3)$ than in those without OIC $(0.8 \pm 1.1)$, indicating that those with OIC were generally sicker. The matched cohort was well balanced on hospital characteristics, with only minor differences in bed capacity and populations served (urban/ rural). Approximately $98 \%$ of all patients were admitted from home, and about $92 \%$ of the hospitalizations were classified as elective.

\section{Medication use}

Use of peripheral $\mu$-opioid receptor antagonists $(1.0 \%$ versus $0.1 \%, p<0.001)$, pro-motility/stool softening agents $(88 \%$ versus $86 \%, p<0.001$ ), and mean number of days of opioid use $(3.5$ versus $3.2, p<0.001)$ were statistically significantly higher in those with OIC versus without OIC, respectively. The mean total oral morphine equivalents for the index encounter were not statistically significantly different in those with OIC (129 $\mathrm{mg} \pm 237 \mathrm{mg}$ ) versus those without OIC (130 mg $\pm 209 \mathrm{mg} ; p=0.44$ ).

\section{Outcomes}

Unadjusted and adjusted index hospitalization LOS and total patient costs are presented in Table 2 . In both the unadjusted and adjusted analyses, LOS and total patient costs were statistically significantly higher in those with OIC versus those without OIC during the index hospitalization. After adjustment, the mean LOS was $\sim 0.3$ day longer, and the mean total patient costs were US\$1214 higher in those with OIC.
Table 3 summarizes unadjusted and adjusted ICU admissions, inpatient mortality, 30-day readmissions, and 30-day ED visits. The proportion of patients with an ICU admission was significantly higher in those with OIC than without OIC $(2.7 \%$ versus $1.9 \%, p<0.0001)$, and this difference remained statistically significant after adjustment (odds ratio [OR] 1.12; 95\% CI: 1.01-1.24). Unadjusted inpatient mortality rates were very low but statistically significantly higher in those with versus without $\mathrm{OIC}(0.14 \%$ versus $0.13 \%, p<0.0001)$. However, after adjustment, the difference was no longer statistically significant (OR 0.89; 95\% CI: 0.59-1.35). Significantly higher rates of all-cause 30 -day hospital readmissions $(9.60 \%$ versus $8.14 \%, p<0.001)$ and $\mathrm{ED}$ visits $(0.41 \%$ versus $0.25 \%, p<0.001)$ were observed in those with OIC versus those without OIC; however, ED visit rates were extremely low overall. After adjustment, the differences remained statistically significant for readmissions (OR 1.16; 95\% CI: 1.11-1.22) and ED visits (OR 1.38; 95\% CI: 1.07-1.79).

\section{Discussion}

This retrospective, observational cohort study evaluated a large, geographically diverse population of hospitalized patients undergoing high-volume orthopedic surgical procedures, often to address joint pain requiring chronic opioids followed by postoperative acute pain management with opioids. A relatively small proportion of patients $(5.2 \%)$ with OIC were identified in the study, likely due to the challenges of identifying OIC using non-specific diagnosis codes. This rate is similar to those reported in larger claims data analyses of patients with chronic non-cancer pain receiving

Table 2 Unadjusted and adjusted hospital LOS and total cost in matched cohort ${ }^{\mathrm{a}}$

\begin{tabular}{|c|c|c|c|c|c|c|}
\hline & \multicolumn{3}{|c|}{ Unadjusted analyses } & \multicolumn{3}{|l|}{ Adjusted analyses } \\
\hline & $\begin{array}{l}\text { With OIC, } \\
\text { mean (SD) }\end{array}$ & $\begin{array}{l}\text { Without OIC, } \\
\text { mean (SD) }\end{array}$ & $p$-value & $\begin{array}{l}\text { With OIC, } \\
\text { mean }(95 \% \mathrm{Cl})\end{array}$ & $\begin{array}{l}\text { Without OIC, } \\
\text { mean }(95 \% \mathrm{Cl})\end{array}$ & $p$-value \\
\hline Index hospitalization LOS (days) & $3.7(2.5)$ & $3.2(1.8)$ & $<0.0001$ & $3.56(3.54-3.57)$ & $3.29(3.27-3.30)$ & $<0.0001$ \\
\hline $\begin{array}{l}\text { Total patient costs for index } \\
\text { hospitalization }\end{array}$ & $\begin{array}{l}\$ 17,746 \\
(\$ 31,151)\end{array}$ & $\begin{array}{l}\$ 16,015 \\
(\$ 8,747)\end{array}$ & 0.008 & $\begin{array}{l}\$ 17,479 \\
(\$ 17,449-\$ 17,510)\end{array}$ & $\begin{array}{l}\$ 16,265 \\
(\$ 16,237-\$ 16,295)\end{array}$ & $<0.000$ I \\
\hline
\end{tabular}

Note: aAll costs shown are in US dollars.

Abbreviations: LOS, length of stay; OIC, opioid-induced constipation.

Table 3 Unadjusted and adjusted ICU admissions, mortality, 30-day readmissions, and 30-day ED visits in matched cohort

\begin{tabular}{|c|c|c|c|c|}
\hline & \multicolumn{3}{|c|}{ Unadjusted analyses } & \multirow{2}{*}{$\begin{array}{l}\text { Adjusted analyses } \\
\text { OR with OIC versus } \\
\text { without OIC }(95 \% \mathrm{CI})\end{array}$} \\
\hline & $\begin{array}{l}\text { With } \\
\text { OIC (\%) }\end{array}$ & $\begin{array}{l}\text { Without } \\
\text { OIC (\%) }\end{array}$ & $p$-value & \\
\hline ICU admissions during index & 2.7 & 1.9 & $<0.0001$ & $1.12(1.01-1.24)$ \\
\hline Death during index hospitalization & 0.14 & 0.13 & $<0.0001$ & $0.89(0.59-1.35)$ \\
\hline 30-day readmissions & 9.6 & 8.1 & $<0.0001$ & $1.16(1.11-1.22)$ \\
\hline 30-day ED visits & 0.4 & 0.3 & 0.0001 & I.38 (I.07-I.79) \\
\hline
\end{tabular}

Abbreviations: ED, emergency department; ICU, intensive care unit; OIC, opioid-induced constipation; OR, odds ratio. 
chronic opioid therapy. ${ }^{8,10}$ Despite the relatively low rate of OIC identified in the overall cohort, in matched analyses, the presence of OIC was found to be statistically significantly associated with greater resource utilization (longer LOS and higher rates of ICU admissions), higher total hospital costs, and higher rates of 30-day readmissions and ED visits. Burden of OIC, similar to that reported here, was observed in 2 other inpatient populations studied: bowel surgery and chest pain without infarction (data not presented). These results add new insights to the existing literature that is largely focused on OIC in patients with chronic non-cancer pain receiving chronic opioid therapy.

The impact of OIC on health care utilization and costs in patients with chronic non-cancer pain has been described. In 1 study using administrative claims data from an ambulatory patient population with chronic non-cancer pain, the odds of hospitalizations $(\mathrm{OR}=2.28, p<0.0001)$ and $\mathrm{ED}$ visits $(\mathrm{OR}=1.79, p<0.0001)$ during a 12 -month observation period were nearly 2 -fold higher in those with OIC versus without OIC. ${ }^{8}$ When restricting the definition of constipation to only those with a relevant diagnosis or procedure code for constipation, similar to what was done in the present study, the authors report similar results but of a higher magnitude (OR unreported). ${ }^{8}$ Mean medical and pharmacy costs over a 12-month observation period were statistically significantly higher in those with OIC (US\$33,044 \pm US $\$ 54,301$ ) versus those without OIC (US\$20,046 \pm US $\$ 58,105, p<0.0001$ ), and the magnitude of these cost differences was even larger when applying the restricted definition of constipation. ${ }^{8}$ In the present study, only total hospital costs during the index surgical encounter, as opposed to all medical and pharmacy costs over a 12-month period, were obtained. As expected, the total cost and magnitude of the difference between those with OIC versus without OIC were smaller. However, patients with OIC in the present study were also more likely to have 30-day readmissions and ED visits, indicating that the overall burden and costs may be substantially higher.

The burden of OIC to patients with chronic non-cancer pain has also been well described. Patients report dissatisfaction with overall treatment, including impairment in activities and reduction in work productivity despite use of laxatives. ${ }^{16,28}$ Substantial discordance between patients' and their health care providers' perceptions of the overall burden of OIC have been documented, ${ }^{29}$ and patients may skip doses or stop opioids to attempt to obtain relief from constipation symptoms, resulting in poor pain management. ${ }^{14}$ Perceived OIC burden in the perioperative setting, as in the current study, is unknown, but these data demonstrate that a unique opportunity exists to implement preoperative strategies directed at improving the identification and treatment of OIC in patients suffering from chronic pain.

Reducing health care resource utilization and costs while maintaining or improving clinical outcomes is imperative for the provision of sustainable, high-quality care. Preventing or more quickly and effectively managing an adverse drug event, such as OIC, in the hospital setting may theoretically translate into reduced resource utilization, decreased costs, and improved outcomes. Studies are needed to confirm or refute this hypothesis. In addition, the specific strategies to screen patients for OIC risk and programs to more effectively manage bowel care in a population of patients undergoing predominantly elective surgical procedures may be derived from existing management strategies in patients with chronic non-cancer pain management, but this would require adaptation and testing to determine if improvements are attainable in real-world clinical practice. ${ }^{1,2,17,18}$

This study has several limitations. First, constipation was identified by ICD coding in the presence of opioid analgesia use. A similar methodology has been used in other studies assessing OIC; however, there may be variation between hospitals in recording these codes, and these codes are not specific for OIC. In addition, data on the presence of constipation and opioid use prior to the hospitalization were not available. Confounding factors, such as concomitant exposure to anesthetics, alterations in diet and fluid intake, and reduction of physical activity, can also contribute to postoperative constipation and were not included in these analyses. Second, associations between OIC and any outcome cannot be interpreted as causal. Third, for the propensity-matching model and adjusted models, there may be unmeasured confounders. Finally, all patient treatment costs are limited to those during the index hospitalization and reflect the direct patient costs of inpatient care. Any estimates on the total costs of constipation are limited and do not include the costs of postdischarge treatment.

\section{Conclusion}

The results of this study demonstrate increased resource utilization and costs associated with OIC in patients receiving pain management in the acute setting of predominantly elective orthopedic surgical procedures. Additional studies are needed to determine if strategies to prevent or mitigate OIC in this population will translate into reduced resource utilization and costs. In the meantime, consideration of perioperative OIC screening and management is warranted in this largely elective surgical population. 


\section{Acknowledgments}

The authors wish to acknowledge Glenn Magee for his contribution to study design, and Carol Cohen who provided editorial support for the manuscript. This study was funded by AstraZeneca. The abstract of this paper was presented at the 22nd Annual Meeting of the International Society for Pharmacoeconomics and Outcomes Research (ISPOR) in Boston, MA, USA, on May 23, 2017, as an abstract presentation with interim findings. The poster's abstract was published in Value Health 2017;20:A182.

\section{Disclosure}

Eric T Wittbrodt, Catherine Datto, and Charles McLeskey are employees of AstraZeneca, and Catherine Datto and Charles McLeskey hold stocks in AstraZeneca. Tong J Gan received honoraria from AstraZeneca. Meenal Sinha is an employee of Premier Applied Services, Premier, Inc., which received funding from AstraZeneca for conducting this study. The authors report no other conflicts of interest in this work.

\section{References}

1. Swegle JM, Logemann C. Management of common opioid-induced adverse effects. Am Fam Physician. 2006;74(8):1347-1354.

2. Camilleri M. Opioid-induced constipation: challenges and therapeutic opportunities. Am J Gastroenterol. 2011;106(5):835-842.

3. Panchal SJ, Müller-Schwefe P, Wurzelmann JI. Opioid-induced bowel dysfunction: prevalence, pathophysiology and burden. Int J Clin Pract. 2007;61(7):1181-1187.

4. Benyamin R, Trescot AM, Datta S, et al. Opioid complications and side effects. Pain Physician. 2008;11(2 Suppl):S105-S120.

5. Papaleontiou M, Henderson CR Jr, Turner BJ, et al. Outcomes associated with opioid use in the treatment of chronic noncancer pain in older adults: a systematic review and meta-analysis. J Am Geriatr Soc. 2010;58(7):1353-1369.

6. Kalso E, Edwards JE, Moore RA, McQuay HJ. Opioids in chronic non-cancer pain: systematic review of efficacy and safety. Pain. 2004;112(3):372-380.

7. Moore RA, McQuay HJ. Prevalence of opioid adverse events in chronic non-malignant pain: systematic review of randomised trials of oral opioids. Arthritis Res Ther. 2005;7(5):R1046-R1051.

8. Fernandes AW, Kern DM, Datto C, Chen Y, McLeskey C, Tunceli O. Increased burden of healthcare utilization and cost associated with opioid-related constipation among patients with noncancer pain. $\mathrm{Am}$ Health Drug Benefits. 2016;9(3):160-170.

9. Mahowald ML, Singh JA, Majeski P. Opioid use by patients in an orthopedics spine clinic. Arthritis Rheum. 2005;52(1):312-321.

10. Iyer S, Davis KL, Candrilli S. Opioid use patterns and healthcare resource utilization in patients prescribed opioid therapy with and without constipation. Manag Care. 2010;19(3):44-51.

11. Bell T, Annunziata K, Leslie JB. Opioid-induced constipation negatively impacts pain management, productivity, and health-related quality of life: findings from the National Health and Wellness Survey. J Opioid Manag. 2009;5(3):137-144.

12. Tuteja AK, Biskupiak J, Stoddard GJ, Lipman AG. Opioid-induced bowel syndrome in patients with chronic non-cancer pain. Neurogastroenterol Motil. 2010;22(4):424-430.
13. Anastassopoulos KP, Chow W, Tapia CI, et al. Economic study on the impact of side effects in patients taking oxycodone controlled-release for noncancer pain. J Manag Care Pharm. 2012;18(8):615-626.

14. Bell TJ, Panchal SJ, Miaskowski C, Bolge SC, Milanova T, Williamson R. The prevalence, severity, and impact of opioid-induced bowel dysfunction: results of a US and European Patient Survey (PROBE 1). Pain Med. 2009;10(1):35-42.

15. Cook SF, Lanza L, Zhou X, et al. Gastrointestinal side effects in chronic opioid users: results from a population-based survey. Aliment Pharmacol Ther. 2008;27(12):1224-1232.

16. LoCasale RJ, Datto CJ, Margolis MK, Tack J, Coyne KS. The impact of opioid-induced constipation among chronic pain patients with sufficient laxative use. Int J Clin Pract. 2015;69(12):1448-1456.

17. LoCasale RJ, Datto C, Margolis MK, Coyne KS. Satisfaction with therapy among patients with chronic noncancer pain with opioid-induced constipation. J Manag Care Spec Pharm. 2016;22(3): 246-253.

18. Coyne KS, Margolis MK, Yeomans K, et al. Opioid-induced constipation among patients with chronic noncancer pain in the United States, Canada, Germany, and the United Kingdom: laxative use, response, and symptom burden over time. Pain Med. 2015;16(8): 1551-1565.

19. Gan TJ, Robinson SB, Oderda GM, Scranton R, Pepin J, Ramamoorthy S. Impact of postsurgical opioid use and ileus on economic outcomes in gastrointestinal surgeries. Curr Med Res Opin. 2015;31(4): 677-686.

20. Marciniak CM, Toledo S, Lee J, et al. Lubiprostone vs Senna in postoperative orthopedic surgery patients with opioid-induced constipation: a double-blind, active-comparator trial. World J Gastroenterol. 2014;20(43):16323-16333.

21. Kremers HM, Larson DR, Crowson CS, et al. Prevalence of total hip and knee replacement in the United States. J Bone Joint Surg Am 2015;97(17):1386-1397.

22. Premier Healthcare Database White Paper: data that informs and performs, February 18, 2018 [webpage on the Internet]. Premier Applied Sciences, Premier Inc. Available from: https://www.premierinc.com/ transforming-healthcare/healthcareperformance-improvement/premierapplied-sciences/. Accessed March 15, 2018.

23. Deyo RA, Cherkin DC, Ciol MA. Adapting a clinical comorbidity index for use with ICD-9-CM administrative databases. J Clin Epidemiol. 1992;45(6):613-619.

24. Wu MJ, Chang CS, Cheng $\mathrm{CH}$, et al. Colonic transit time in long-term dialysis patients. Am J Kidney Dis. 2004;44(2):322-327.

25. Chey WD, Webster L, Sostek M, Lappalainen J, Barker PN, Tack J. Naloxegol for opioid-induced constipation in patients with noncancer pain. N Engl J Med. 2014;370(25):2387-2396.

26. Feng WW, Jun Y, Xu R. A method/macro based on propensity score and mahalanobis distance to reduce bias in treatment comparison in observational study; SAS SUGI, Paper PR 05. Available from: http:// www.lexjansen.com/pharmasug/2006/publichealthresearch/pr05.pdf. Accessed June 29, 2017.

27. Li Z., Mahendra G. Using "Recycled Predictions" for computing marginal effects, statistics and data analysis, SAS Global Forum 2010, Paper 272-2010. Available from: http://support.sas.com/resources/ papers/proceedings10/272-2010.pdf. Accessed June 29, 2017.

28. Coyne KS, LoCasale RJ, Datto CJ, Sexton CC, Yeomans K, Tack J. Opioid-induced constipation in patients with chronic noncancer pain in the USA, Canada, Germany, and the UK: descriptive analysis of baseline patient-reported outcomes and retrospective chart review. Clinicoecon Outcomes Res. 2014;6:269-281.

29. LoCasale RJ, Datto C, Wilson H, Yeomans K, Coyne KS. The burden of opioid-induced constipation: discordance between patient and health care provider reports. J Manag Care Spec Pharm. 2016;22(3): 236-245. 


\section{Supplementary material}

Table SI Patient and hospital characteristics for the overall cohort with and without $\mathrm{OIC}^{\mathrm{a}}$

\begin{tabular}{|c|c|c|c|c|}
\hline & \multicolumn{4}{|c|}{ Overall cohort, $N=788,448$} \\
\hline & All & With OIC, $n=40,891$ & Without OIC, $n=747,557$ & $p$-value \\
\hline Age, years, mean (SD) & $66(\mathrm{II})$ & $68(\mathrm{II})$ & $66(\mathrm{II})$ & $<0.001$ \\
\hline Sex, men & 39.9 & 37.1 & 40.1 & $<0.001$ \\
\hline \multicolumn{5}{|l|}{ Race } \\
\hline Caucasian & 80.8 & 81.3 & 80.7 & \multirow{3}{*}{0.002} \\
\hline Black & 8.0 & 8.0 & 8.0 & \\
\hline Other & 11.2 & 10.7 & 11.3 & \\
\hline \multicolumn{5}{|l|}{ Payer } \\
\hline Medicare & 55.5 & 63.6 & 55.0 & \multirow{4}{*}{$<0.001$} \\
\hline Medicaid & 3.8 & 3.8 & 3.8 & \\
\hline Managed care & 29.3 & 22.6 & 29.6 & \\
\hline Other & 11.4 & 10.1 & 11.5 & \\
\hline \multicolumn{5}{|l|}{ Admission source } \\
\hline Home & 98.4 & 98.4 & 98.4 & \multirow{4}{*}{$<0.001$} \\
\hline Transferred from acute care facility & 0.6 & 0.8 & 0.6 & \\
\hline $\begin{array}{l}\text { Transferred from skilled nursing } \\
\text { facility }\end{array}$ & 0.2 & 0.2 & 0.2 & \\
\hline Other/unknown & 0.8 & 0.6 & 0.8 & \\
\hline \multicolumn{5}{|l|}{ Admission type } \\
\hline Elective & 94.0 & 93.4 & 94.1 & \multirow{5}{*}{$<0.001$} \\
\hline Emergency & 1.9 & 3.5 & 1.8 & \\
\hline Trauma & 0.0 & 0.1 & 0.0 & \\
\hline Urgent & 3.7 & 2.7 & 3.8 & \\
\hline Other & 0.3 & 0.3 & 0.3 & \\
\hline \multicolumn{5}{|l|}{ Comorbidities during index encounter } \\
\hline Myocardial infarction & 3.5 & 4.4 & 3.5 & $<0.001$ \\
\hline Heart failure & 2.6 & 4.1 & 2.5 & $<0.001$ \\
\hline Peripheral vascular disease & 2.2 & 3.0 & 2.1 & $<0.001$ \\
\hline Cerebrovascular disease & 0.7 & 1.1 & 0.7 & $<0.001$ \\
\hline Dementia & 0.1 & 0.1 & 0.1 & $<0.001$ \\
\hline Chronic pulmonary disease & 15.5 & 18.3 & 15.4 & $<0.001$ \\
\hline Rheumatologic disease & 4.3 & 4.9 & 4.2 & $<0.001$ \\
\hline Peptic ulcer disease & 0.5 & 0.8 & 0.5 & $<0.001$ \\
\hline Mild liver disease & 0.3 & 0.4 & 0.3 & 0.05 \\
\hline Moderate-to-severe liver disease & 0.0 & 0.0 & 0.0 & 0.24 \\
\hline Diabetes & 18.4 & 19.3 & 18.3 & $<0.001$ \\
\hline Diabetes with chronic complications & 1.4 & 2.1 & 1.4 & $<0.001$ \\
\hline Hemiplegia or paraplegia & 0.1 & 0.1 & 0.1 & $<0.001$ \\
\hline Renal disease & 5.3 & 8.3 & 5.1 & $<0.001$ \\
\hline Any malignancy & 1.0 & 1.4 & 1.0 & $<0.001$ \\
\hline Metastatic solid tumor & 0.1 & 0.3 & 0.1 & $<0.001$ \\
\hline AIDS/HIV & 0.1 & 0.1 & 0.1 & 0.37 \\
\hline Charlson Comorbidity Index, mean (SD) & $0.7(\mathrm{I} . \mathrm{I})$ & $0.9(1.3)$ & $0.7(1.0)$ & $<0.001$ \\
\hline Chronic pain & 4.4 & 7.1 & 4.2 & $<0.001$ \\
\hline Hemodialysis & 0.2 & 0.4 & 0.2 & $<0.001$ \\
\hline Use of peripheral $\mu$-opioid receptor antagonists & 0.1 & 1.0 & 0.1 & $<0.001$ \\
\hline $\begin{array}{l}\text { Use of selected pro-motility drugs and stool } \\
\text { softeners }\end{array}$ & 86.1 & 88.5 & 85.9 & $<0.001$ \\
\hline $\begin{array}{l}\text { Total oral morphine equivalents }(\mathrm{mg}) \text { for index } \\
\text { hospitalization, mean (SD) }\end{array}$ & II 5.3 (I86.7) & I29.| (236.8) & II $4.6(183.6)$ & $<0.001$ \\
\hline Total days of opioid use, mean (SD) & $3.1(1.5)$ & $3.5(2.1)$ & $3(1.5)$ & $<0.001$ \\
\hline
\end{tabular}


Table SI (Continued)

\begin{tabular}{|c|c|c|c|c|}
\hline & \multicolumn{4}{|c|}{ Overall cohort, $N=788,448$} \\
\hline & $\overline{\text { All }}$ & With OIC, $n=40,89 I$ & Without OIC, $n=747,557$ & $\overline{p \text {-value }}$ \\
\hline \multicolumn{5}{|c|}{ Hospital geographic divisions } \\
\hline New England & 5.4 & 3.2 & 5.5 & \multirow{9}{*}{$<0.001$} \\
\hline Middle Atlantic & 10.4 & 14.7 & 10.1 & \\
\hline East North Central & 13.4 & 19.6 & 13.0 & \\
\hline West North Central & 6.4 & 8.9 & 6.3 & \\
\hline South Atlantic & 28.5 & 22.5 & 28.8 & \\
\hline East South Central & 9.7 & 9.9 & 9.7 & \\
\hline West South Central & 8.4 & 7.6 & 8.5 & \\
\hline Mountain & 7.0 & 5.5 & 7.0 & \\
\hline Pacific & 10.9 & 8.1 & II.I & \\
\hline \multicolumn{5}{|l|}{ Hospital bed capacity } \\
\hline$<150$ & 14.6 & 12.8 & 14.7 & \multirow{6}{*}{$<0.001$} \\
\hline $150-249$ & 17.7 & 15.0 & 17.9 & \\
\hline $250-349$ & 20.0 & 20.4 & 19.9 & \\
\hline $350-449$ & 16.7 & 15.6 & 16.7 & \\
\hline $450-549$ & 13.3 & 18.2 & 13.0 & \\
\hline$\geq 550$ & 17.8 & 18.1 & 17.8 & \\
\hline Hospital - urban setting & 89.1 & 90.7 & 89.0 & $<0.001$ \\
\hline Teaching hospital & 40.1 & 47.3 & 39.8 & $<0.001$ \\
\hline
\end{tabular}

Note: aAll values are $\%$ unless otherwise specified.

Abbreviation: OIC, opioid-induced constipation.

Journal of Pain Research

\section{Publish your work in this journal}

The Journal of Pain Research is an international, peer reviewed, open access, online journal that welcomes laboratory and clinical findings in the fields of pain research and the prevention and management of pain. Original research, reviews, symposium reports, hypothesis formation and commentaries are all considered for publication.

\section{Dovepress}

The manuscript management system is completely online and includes a very quick and fair peer-review system, which is all easy to use. Visit http://www.dovepress.com/testimonials.php to read real quotes from published authors. 